\title{
Attitudes of High School Students Regarding Intimate Relationships and Gender Norms in New Providence, The Bahamas
}

Donna Nicolls, Bahamas Crisis Centre Camille Russell-Smith, The College of The Bahamas

Sandra Dean-Patterson, Bahamas Crisis Centre Lindel D. Deveaux-Stuart, Ingrid Gibson-Mobley, Elizabeth J. Williams, A. Pinder-Darling, and William J. Fielding The College of The Bahamas ${ }^{1}$

\section{ABSTRACT}

This paper reports the attitudes and actions on relationships with the opposite sex of 1,002 Grade 10 and Grade 12 students in New Providence. Girls were more likely than boys to use aggressive behaviours in teen relationships. Some of the behaviours noted in teen relationships informed expectations of marital relationships, such as restricted access to friends of the opposite sex. The students endorsed a number of sex-related stereotypes, such as a man being the head of the household. Both male and female students indicated that it was acceptable for men to control their wives. Participation in aggressive and controlling behaviours by teens points to the need to educate students about how to develop more respectful relationships.

\section{INTRODUCTION}

In common with countries in the Caribbean and elsewhere, The Bahamas has been subjected to increased levels of violence, has a relatively high incidence of rape in the Caribbean (United Nations Office on Drugs and Crime and the Latin American and Caribbean Region of the World Bank, 2007) and domestic and sexual violence continue to be a concern in The Bahamas (U.S. Department of State. Overseas Security Advisory Council, 2012). These events have forced the country to focus more and more on crime prevention (Bahamas Information Services, 2012).

Blank (2005) highlighted that interpersonal relationships of Bahamian youth was an area

\footnotetext{
1 Donna Nicolls, Assistant Director, Bahamas Crisis Centre; Camille Russell-Smith, Counsellor II, Counselling Department, The College of The Bahamas; Sandra Dean-Patterson, Director, Bahamas Crisis Centre; Lindel'D. Deveaux-Stuart, Ingrid Gibson-Mobley, Elizabeth J. Williams, Assistant Professors, School of Nursing and Allied Health Professions; Antoinette Pinder-Darling, Librarian II, Academic Affairs Department and William J. Fielding, Director of Planning, The College of The Bahamas, P.O. Box N-4912, Nassau, Bahamas.

Acknowledgements: We are grateful to the Crisis Centre Volunteers, The Ministry of Education, Science and Technology, The Ministry of Social Services, Zonta Club and Rotary Club, Volunteer Bahamas, The Women's Bureau and other interested individuals who delivered the programme in the schools. We are grateful to the Health Information Unit of The Bahamas Ministry of Health for its assistance with formulating the questions and to College of The Bahamas student Rembert Mortimer for assistance with the data entry.

Corresponding author: camille.smith@cob.edu.bs

Note: An error in Table 8 was corrected following publication.

APA Reference: Nicolls, D., Russell-Smith, C., Dean-Patterson, S., Deveaux-Stuart, L. D., Gibson-Mobley, I., Williams, E. J, Pinder-Darling, A., \& Fielding, W. J. (2014). Attitudes of high school students regarding intimate relationships and gender norms in New Providence, The Bahamas. The International Journal of Bahamian Studies, 20(1), 38-51. https://doi.org/ 10.15362/ijbs.v20i1.225
}

(c) D. Nicolls et al., 2014. Journal compilation (CThe International Journal of Bahamian Studies, 2014 
of concern, and sexual relations can be risky due to unprotected sexual intercourse ( $\mathrm{Yu}$ et al, 2007).

Teen relationships can result in live births; 617 in 2008, 532 in 2009 and 507 in 2010 (Bahamas Department of Statistics, 2012). ${ }^{2}$ While the number of reported rape cases has been generally declining since 2006, the number of cases of unlawful sexual intercourse has not, as illustrated in Figure 1.

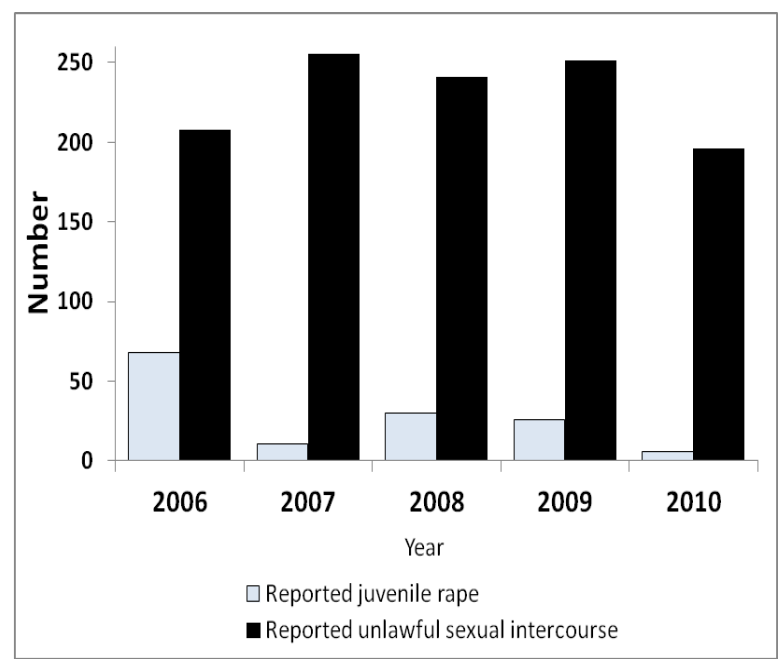

Figure 1. Reported number of juvenile female rapes and unlawful sexual intercourse in The Bahamas. Data from Bahamas Crisis Centre (2011) \& Royal Bahamas Police Force (n.d.).

In The Bahamas, anecdotal information from guidance counsellors, social workers, the Royal Bahamas Police Force and the Bahamas Crisis Centre suggests that increasing numbers of children are experiencing sexual abuse and/or abusive intimate relationships (Concerning Child Abuse Figures, 2014). In 2011, 167 child sexual abuse cases and 11 incest cases were reported (Bahamas Department of Social Services, 2012). Between 2007 and 2011, the number of clients seen at the Bahamas Crisis Centre moved from 770 to 1,285 . Over the same period, the number of new cases of children (those under 18 years) seen in the Bahamas

2 Relationships which result in pregnancy have been studied by Moss-Knight (2010).
Crisis Centre declined slightly from 96 in 2007 to 81 in 2011, but the percentage of those who were males increased, from $38 \%$ in 2007 to $46 \%$ in 2011 . The longer-term effect of sexual abuse of teens can result in their having attitudes about intimate relationships that permit abuse, including domestic violence (Barter, McCarry, Berridge \& Evans, 2009).

In the United States, teenagers experience violence in their intimate or dating relationships. The prevalence of physical dating violence was around 9\% from 1999 to 2003, and 10\% from 2004 to 2009 (Henry \& Zeytinoglu, 2012). In the Caribbean, similar findings have emerged. Le Franc et al. (2008) claimed that in Barbados, Jamaica and Trinidad and Tobago, that "a culture of violence and adversarial intimate relationships may be well entrenched" (p. 409).

The UNICEF State of The World's Children 2011 report states that physical, sexual or psychological acts of violence take place within the home, at school, and in the community. The full scale of violence against adolescents is impossible to measure given that most abuse occurs in secret. In every country assessed, violence was an important problem. Additionally, it was noted that more than one third of adolescent males aged 15-19 considered a husband justified in hitting or beating his wife. In The Bahamas, $11 \%$ of college students reported that it could be acceptable for a husband to slap his wife while only $4 \%$ of students from the United States of America felt this way (Risley-Curtiss \& Fielding, 2012). Excessive controlling behaviours put females at risk of femicide and demonstrate the ultimate outcome of inadequately formed relationships (Fukuroda, 2005).

These observations make it important to ascertain the attitudes of teens regarding relationships, particularly as many are 
exposed to violence at home (Carroll, Fielding, Brennen \& Hutcheson, 2011) and at school (Reynolds, 2009) although a relationship between parental values and those of children in The Bahamas is yet to be demonstrated (Lui et al., 2007).

\section{Purpose of study}

This study was designed to investigate the perspectives of teenagers in The Bahamas on interpersonal relationships and the prevalence of violence experienced in relationships, particularly those of a romantic nature. Relationships considered intimate can take many forms (Coy \& Miller, 2014), but for the purpose of this study we consider these relationships to be emotional/romantic in nature and not necessarily sexual. Tharp et al. (2011) remind us that teen dating violence is a preventable public health problem and that dating violence typically starts at school, so making interventions at this stage is important. Appropriate training during school years can promote healthy relationships with their attendant long-term benefits (Crooks, Chiodo, Zwarych, Hughes, \& Wolfe, 2013).

\section{METHODOLOGY}

The target population for this study was 1,000 adolescent boys and girls in Grades 10 and 12, thus covering those aged about 15 to 18 years. Students in Grades 10 and 12 were chosen for this study as these were the grades in which the Bahamas Crisis Centre was making its presentations on healthy teen relationships. Only those students who participated in the training given by the Bahamas Crisis Centre were surveyed. All government high schools and selected private high schools in New Providence were included in the study.

A team at the Bahamas Crisis Centre developed the questionnaire with assistance from the Health Information Unit of The Bahamas Ministry of Health. The Liz Claibourne on-line forum (Teenage Research Unlimited, 2006) and training facility on teen relationship violence guided the development of some of the questions. Other questions were taken from Weller and Clifford (2008). The questionnaire collected information on demographics and information on relationships. Volunteers were trained to present a healthy relationship script prepared by the Bahamas Crisis Centre and the Zonta Club. The questionnaire was administered before the presentation to the classes of Grades 10 and 12 students. The survey took about 10 minutes to complete. The process was monitored by the presenter and, in some cases, a teacher. Permission for this study was given by the Ministry of Education, Youth, Sports and Culture. Interviews took place during 2011.

\section{RESULTS}

The total number of respondents was 1,002 from eight schools, which included one private school. Not all forms were completed, so this represents the maximum sample size. A minority of students were male, $45.2 \%$ of 960 respondents, and $13.1 \%$ of 945 students were in Grade 10. The mean age of the Grade 10 students was 15 years, $S E=0.74$, and that for the Grade 12 students $M=16.8$ years, $S E$ $=0.03$.

\section{Family structure}

The majority, $88.1 \%$, of students lived in homes with a mother figure (mother or stepmother) and over half lived in homes with a father figure, 53.2\%, as illustrated in Table 1.

Students who lived with both father and mother figures were in the minority, 40\%; $21.7 \%$ lived with a grandmother. When a grandmother was in the home, a father figure was less likely to be present than a mother figure as illustrated in Figure 2. We use the term father/mother figure to include either a biological or non-biological parent as in Coffino (2009); no formal legal status of the person to the child is assumed: for example, a father's girl-friend or step-mother may take 
the place of the absent biological mother.

Table 1

Other family members living in respondents' homes

\begin{tabular}{lrr}
\hline Live with: & \multicolumn{1}{l}{$\%$} & \multicolumn{1}{c}{$n$} \\
\hline Mother & 84.1 & 955 \\
Step-mother & 4 & 831 \\
Father & 39.9 & 885 \\
Step-father & 13.3 & 835 \\
Grandmother & 21.7 & 840 \\
Siblings & 62.9 & 903 \\
Other family members & 21.6 & 850 \\
\hline
\end{tabular}

Most respondents came from homes in which both parental figures $(67.3 \%)$ worked; mother figures did not work in $13.3 \%$ of homes $(n=$ 889). Boys were more likely than girls to work; $19.9 \%$ of boys worked compared with $9.1 \%$ of girls. Overall, boys worked more than girls. 2.3 hours per week $(S E=34)$ for boys and 0.6 hours per week $(S E=.14)$ for girls (Mann-Witney $U=83,996, Z=-4.892, p$ $<.001, n=876)$.

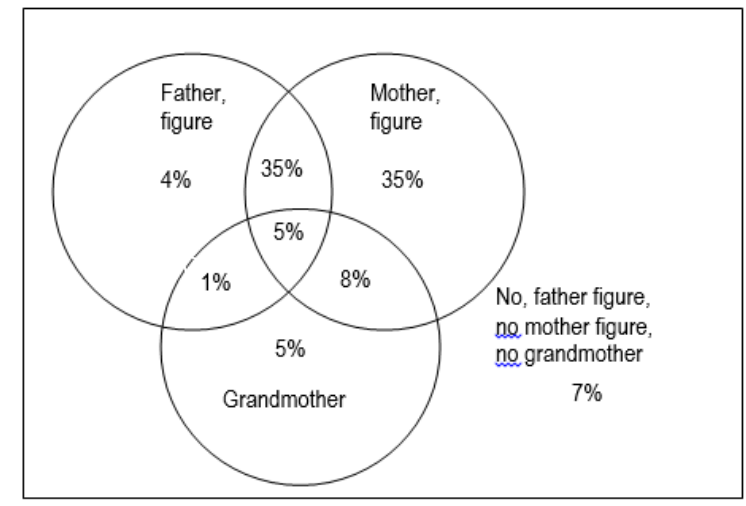

Figure 2. Composition of student households, including parents, step-parents and grandmothers

Experiences of teen relationships

Boys and girls were just as likely to have been on a date, odds ratio $=1.07,95 \%$ CI $[0.77$, 1.50] and to have had a boyfriend/girlfriend relationship, odds ratio $=0.81,95 \%$ CI $[0.45$, 1.46]. However, boys were less likely than girls to have been in a serious relationship, odds ratio $=0.66,95 \%$ CI $[0.48,0.90]$, but boys were more likely than girls to have been pressured into a relationship, odds ratio = $2.04,95 \%$ CI [1.41, 2.94].
Table 2

Percentage of students in a relationship

\begin{tabular}{lrrr}
\hline \multicolumn{1}{c}{ Question } & Male & Female & Fisher's $p$ \\
\hline $\begin{array}{l}\text { Have you ever been on a } \\
\text { date? }\end{array}$ & $81.2 \%$ & $80.1 \%$ & .734 \\
$\begin{array}{l}\text { Have you ever been in a } \\
\text { boy/girlfriend relationship? }\end{array}$ & $94.2 \%$ & $95.2 \%$ & .547 \\
$\begin{array}{l}\text { Have you ever been in a } \\
\text { serious boy/ girlfriend } \\
\text { relationship? }\end{array}$ & $72.6 \%$ & $80 \%$ & .011 \\
$\begin{array}{l}\text { Do/did you feel pressured } \\
\text { to have a boy/girl friend? }\end{array}$ & $21 \%$ & $11.6 \%$ & $<.001$ \\
\hline
\end{tabular}

Boys typically did not date girls older than themselves, whereas the opposite was the case with girls. Only $7.1 \%$ of boys dated a girl from an age group older than their own, compared to $30.5 \%$ of girls (Table 3). Relatively few girls dated boys who were much older than they were. Boys were more likely than girls to think that it was good for their girl/boyfriend to be controlling and both boys and girls were equally likely to think that it was acceptable for their girl/boyfriend to be jealous and want to call often (Table 4).

Table 3

Ages of most recent dating relationship

\begin{tabular}{|c|c|c|c|c|c|c|}
\hline \multicolumn{2}{|c|}{ Respondent } & \multicolumn{5}{|c|}{ How old was the last person you dated? } \\
\hline Sex & Age & $<16$ & $16-18$ & $19-25$ & $>26$ & $\mathrm{~N}$ \\
\hline \multirow{6}{*}{$\frac{\frac{\Phi}{\pi}}{\sum}$} & 14 & $100 \%$ & & & & 3 \\
\hline & 15 & $70 \%$ & $30 \%$ & & & 20 \\
\hline & 16 & $20.4 \%$ & $74.2 \%$ & $5.4 \%$ & & 93 \\
\hline & 17 & $16.2 \%$ & $79 \%$ & $4.2 \%$ & $0.6 \%$ & 167 \\
\hline & 18 & $14 \%$ & $76 \%$ & $6 \%$ & $4 \%$ & 50 \\
\hline & 19 & & $100 \%$ & & & 4 \\
\hline \multirow{6}{*}{ 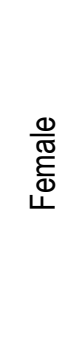 } & 14 & $33.3 \%$ & $66.7 \%$ & & & 12 \\
\hline & 15 & $18.5 \%$ & $66.7 \%$ & $14.8 \%$ & & 27 \\
\hline & 16 & $2.8 \%$ & $77.3 \%$ & $19.9 \%$ & & 141 \\
\hline & 17 & $2.3 \%$ & $70.6 \%$ & $25.2 \%$ & $1.9 \%$ & 214 \\
\hline & 18 & & $61.8 \%$ & $38.2 \%$ & & 55 \\
\hline & 19 & & $25 \%$ & $50 \%$ & $25 \%$ & 4 \\
\hline
\end{tabular}

Figures in bold are the modal values within each age group. 
Table 4

Occurrence of selected behaviours acceptable

\begin{tabular}{llll}
\hline Percentage agreeing: & Boys & Girls & Fisher's $p$ \\
\hline $\begin{array}{l}\text { It's OK for a boy/girlfriend to } \\
\text { be really jealous at times }\end{array}$ & $74.9 \%$ & $70.1 \%$ & .185 \\
$\begin{array}{l}\text { It's really good for a boy/girl } \\
\text { friend to call many times }\end{array}$ & & & \\
$\begin{array}{l}\text { every day if s/he really } \\
\text { loves you }\end{array}$ & & & \\
$\begin{array}{l}\text { It's good for a boy/girl friend } \\
\text { to be controlling }\end{array}$ & $26.3 \%$ & $12.4 \%$ & $<.001$ \\
\hline Note: Respondents who were neutral were omitted &
\end{tabular}

Both boys and girls were subjected to controlling behaviours by their partners, as shown in Table 5, but not always to the same extent.

Table 5

Experiences in relationships by sex.

\begin{tabular}{|c|c|c|c|}
\hline & Boys & Girls & Fisher's $p$ \\
\hline $\begin{array}{l}\text { Asked where you were all the } \\
\text { time }\end{array}$ & $46.2 \%$ & $47.1 \%$ & .833 \\
\hline $\begin{array}{l}\text { Asked you to only spend time } \\
\text { with him/her }\end{array}$ & $40.3 \%$ & $27.6 \%$ & $<.001^{*}$ \\
\hline $\begin{array}{l}\text { Asked who you were with all } \\
\text { the time }\end{array}$ & $39.0 \%$ & $41.4 \%$ & .523 \\
\hline $\begin{array}{l}\text { Tried to stop you from } \\
\text { spending time with your family } \\
\text { or friends }\end{array}$ & $14.1 \%$ & $9.6 \%$ & . 048. \\
\hline $\begin{array}{l}\text { Threatened to hurt himself } \\
\text { /herself if you left }\end{array}$ & $16.6 \%$ & $18.1 \%$ & .643 \\
\hline $\begin{array}{l}\text { Threatened to hurt you if you } \\
\text { left }\end{array}$ & $12.1 \%$ & $13.5 \%$ & .600 \\
\hline $\begin{array}{l}\text { Threatened to kill him/herself if } \\
\text { you left }\end{array}$ & $11.7 \%$ & $11.6 \%$ & $>.99$ \\
\hline $\begin{array}{l}\text { Threatened to spread rumours } \\
\text { about you if you did not do } \\
\text { what s/he wanted }\end{array}$ & $9.6 \%$ & $4.3 \%$ & $.003^{*}$ \\
\hline Threatened to kill you if you left & $6 . \%$ & $9.6 \%$ & .084 \\
\hline $\begin{array}{l}\text { Felt nervous about doing } \\
\text { something that } \\
\text { boy/girlfriend doesn't like }\end{array}$ & $41.1 \%$ & $36.9 \%$ & .242 \\
\hline $\begin{array}{l}\text { Tried to tell you what to do a lot } \\
\text { Tried hard to get your boy/qirl }\end{array}$ & $31.2 \%$ & $22.9 \%$ & $.009^{*}$ \\
\hline $\begin{array}{l}\text { friend to change his/her } \\
\text { beliefs/values }\end{array}$ & $31.1 \%$ & $38.1 \%$ & . 043 \\
\hline $\begin{array}{ll}\text { Did something against } & \text { your } \\
\text { beliefs to please } & \text { your } \\
\text { boy/girlfriend because } & \text { s/he } \\
\text { really loves you } & \end{array}$ & $29.4 \%$ & $27 . \%$ & .475 \\
\hline
\end{tabular}

Girls were generally more aggressive than boys in their relationships, but both were equally unlikely to use weapons as a means of coercion. See Table 6 below for details.

\section{Table 6}

Occurrence of violence in teen relationships.

\begin{tabular}{lrrr}
\hline Behaviour: & Boys & \multicolumn{1}{c}{ Girls } & Fisher's $p$ \\
\hline Called you names & $51.6 \%$ & $35 \%$ & $<.001$ \\
Hit/slapped you & $28.1 \%$ & $19.8 \%$ & .033 \\
Pushed/shoved you & $28.2 \%$ & $20.3 \%$ & .004 \\
Hurt you with a weapon & $3.8 \%$ & $2.6 \%$ & .122 \\
\hline Percentage reporting that the behaviour ever occurred.
\end{tabular}

Using the attitudes in Table 5, a logistic regression investigated the association with actions in Table 4, which occurred more than once in experienced relationships, and the sex of the respondent. A stepwise backward elimination regression (using $p>.10$ level for elimination) was used. Only acting jealously and thinking that it is good for a partner to be controlling were related to the variables listed in Table 6, as reported in Table 7. Although sex was not linked to attitudes towards jealously, slapping was linked. The use of weapons was rare (as seen in Table 6) but their use was linked with attitudes towards controlling behaviours (Table 7).

\section{Table 7}

Association between the acceptability of controlling behaviours and controlling behaviours experienced in relationships

\begin{tabular}{llll}
\hline & OR & & $95 \% \mathrm{Cl}$ \\
\hline It's OK for a boy/girl friend to be & & & \\
really jealous at times linked to: & & & \\
Slapped by partner (never or 0.40 & 0.19 & 0.88 \\
once compared with more than \\
once)
\end{tabular}


Attitudes towards future relationships/actions There were consistent differences between boys and girls in their attitudes to adult relationships but these attitudes were also endorsed by both girls and boys. Despite the differences in the responses between the sexes, the majority of boys and girls subscribed to traditional ideas that men should be the heads of their households and control their wives. The expectation that a wife should have sex with her husband whenever he wants was correlated with the expectation that the man must be the head of the household, for both female (Kendal's $\tau(494)$ $.128, p<.001)$ and male respondents (Kendal's $\tau(398) .113, p<.001$ ). Table 9 illustrated the need for mutual respect by both partners was indicated by the similar responses for the need for both parties to submit to each other. Both boys and girls expected their wives/husbands to stay with them (i.e. remain married) even if the relationship was not going well. Although the percentages were not large, boys and girls accepted that men could be violent towards their wives as a form of expressing their love and that women must have sexual intercourse with their husbands on demand. Aspects of their current relationships, such as jealousy if time was spent with others and the expectation that other friendships would be limited (Table 5), were expected to continue in their adult relationships.

Link between violence in experienced relationships and expectations for adult relationships

For those attitudes in Table 8 which were violence-related, a logistic regression was performed to determine if agreement expressed by respondents was related to actions in Table 6, which occurred more than once in experienced relationships. A stepwise backward elimination regression (using $p>$ .10 level for elimination) was used. The analysis indicated that after the respondent's sex was associated with their attitudes, the calling of names was the second most important factor. Use of a weapon was only associated with "slapping up" a woman "to show who is boss".

\section{Table 8}

Attitudes of boys and girls towards aspects of adult relationships

\begin{tabular}{|c|c|c|c|}
\hline $\begin{array}{l}\text { Percentages agreeing } \\
\text { with these statements: }\end{array}$ & Boys & Girls & Fisher's $p$ \\
\hline $\begin{array}{l}\text { A woman who dresses } \\
\text { too sexy deserves to } \\
\text { get hit by her partner }\end{array}$ & $15.9 \%$ & $6.6 \%$ & $<.001^{*}$ \\
\hline $\begin{array}{l}\text { Some women are to } \\
\text { blame for the licks they } \\
\text { get from their partners }\end{array}$ & $58.1 \%$ & $32 \%$ & $<.001^{*}$ \\
\hline $\begin{array}{l}\text { A man must be head } \\
\text { of the household }\end{array}$ & $97.0 \%$ & $86.7 \%$ & $<.001^{*}$ \\
\hline $\begin{array}{l}\text { Men should discipline } \\
\text { their female partners }\end{array}$ & $37.7 \%$ & $12.3 \%$ & $<.001^{*}$ \\
\hline $\begin{array}{l}\text { A man must slap-up } \\
\text { his women to show } \\
\text { who is boss }\end{array}$ & $9.1 \%$ & $1.8 \%$ & $<.001^{*}$ \\
\hline $\begin{array}{l}\text { A woman's place is in } \\
\text { the home }\end{array}$ & $58.4 \%$ & $36.8 \%$ & $<.001^{*}$ \\
\hline $\begin{array}{l}\text { Women should ask } \\
\text { permission from their } \\
\text { partners if they want to } \\
\text { go out }\end{array}$ & $49.2 \%$ & $16.6 \%$ & $<.001^{*}$ \\
\hline $\begin{array}{l}\text { A woman should } \\
\text { submit to her husband }\end{array}$ & $87.3 \%$ & $85.4 \%$ & .505 \\
\hline $\begin{array}{l}\text { A man should submit } \\
\text { to his wife }\end{array}$ & $75.5 \%$ & $85.1 \%$ & $.002^{*}$ \\
\hline $\begin{array}{l}\text { A wife must have sex } \\
\text { when her husband } \\
\text { wants to }\end{array}$ & $45.6 \%$ & $16.1 \%$ & $<.001^{*}$ \\
\hline $\begin{array}{l}\text { A man must stay with } \\
\text { his wife }\end{array}$ & $75.5 \%$ & $68.5 \%$ & .044 \\
\hline $\begin{array}{l}\text { A woman should stay } \\
\text { with her husband }\end{array}$ & $73.1 \%$ & $62.6 \%$ & $.003^{*}$ \\
\hline $\begin{array}{l}\text { A woman must not } \\
\text { have male friends }\end{array}$ & $12.2 \%$ & $7.1 \%$ & .017 \\
\hline $\begin{array}{l}\text { A man must not have } \\
\text { female friends }\end{array}$ & $10.7 \%$ & $16.7 \%$ & .020 \\
\hline
\end{tabular}


Table 9

Factors related to attitudes towards violent aspects of adult relationships.

Agreeing with
statements: OR $95 \% \mathrm{Cl}$

\begin{tabular}{|c|c|c|c|}
\hline \multicolumn{4}{|c|}{$\begin{array}{l}\text { A woman who dresses too sexy deserves to get hit } \\
\text { by her partner linked with }\end{array}$} \\
\hline $\begin{array}{l}\text { Sex (Males compared } \\
\text { with females) }\end{array}$ & 3.39 & 1.88 & 6.13 \\
\hline $\begin{array}{l}\text { Called names in an } \\
\text { experienced relationship, } \\
\text { never or once compared }\end{array}$ & 0.62 & 0.39 & 1.09 \\
\hline
\end{tabular}

\begin{tabular}{|c|c|c|c|}
\hline \multicolumn{4}{|c|}{ A wife must have sex when her husband wants } \\
\hline $\begin{array}{l}\text { Sex (Males compared } \\
\text { with females) }\end{array}$ & 4.61 & 3.08 & 6.90 \\
\hline \multicolumn{4}{|c|}{$\begin{array}{l}\text { A man must slap-up his woman to show who is } \\
\text { boss linked with }\end{array}$} \\
\hline $\begin{array}{l}\text { Sex (Males compared } \\
\text { with females) }\end{array}$ & 4.24 & 1.75 & 10.26 \\
\hline $\begin{array}{l}\text { Called names in a } \\
\text { relationship, never or } \\
\text { once compared with } \\
\text { more than once }\end{array}$ & 0.36 & 0.17 & 0.79 \\
\hline $\begin{array}{l}\text { Hurt you with a weapon } \\
\text { in a relationship, never or } \\
\text { once compared with } \\
\text { more than once }\end{array}$ & 0.14 & 0.02 & 0.90 \\
\hline
\end{tabular}

Some women are to blame for the licks they get from their partners linked with

$\begin{array}{llll}\begin{array}{l}\text { Sex (Males compared } \\ \text { with females) }\end{array} & 2.52 & 1.76 & 3.61 \\ \begin{array}{l}\text { Called names in } \\ \text { experienced relationship, } \\ \text { never or once compared }\end{array} & 0.59 & 0.39 & 0.88 \\ \begin{array}{l}\text { with more than once } \\ \text { nan }\end{array} & & & \end{array}$

\section{DISCUSSION}

All studies have limitations, and so care should be exercised in extrapolating the results from this study to all Grade 10 and 12 students in New Providence. The sample respondents were not randomly chosen from the approximately 4,800 students in these grades (Bahamas Ministry of Education, 2008). However, the extensive coverage, about $21 \%$, of the population might offset possible sampling bias. Only those students whom the Crisis Centre was able to include in its training on healthy relationships were surveyed.

While the origins of the accepted use of violence in relationships in Caribbean countries may be open to debate (originating in slavery, UNICEF, 2006; or religion, Otterbein \& Otterbein, 1973), this is not necessarily helpful as attempts have to be made to deal with violence in a modern society which bears increasingly less resemblance to "traditional" norms. For example, in $1970,71 \%$ of live births occurred in wedlock. By 2010, this had dropped to $39 \%$ (Bahamas Department of Statistics, 2012). Today, violence in homes challenges the longstanding belief that homes and family are places and sources of love and protection (Carroll, et al, 2011).

In this study, typically both parental figures worked. This observation blurs the traditional view of men being the breadwinner, or at least the sole breadwinner. Further, when male parental figures were absent from the household, they tended to be replaced by a grandmother, resulting in respondents being more likely to be brought up in a female, rather than male, dominated environment, and so be exposed to traditional views. This is consistent with the matrifocal nature of Bahamian homes (Bethel, Minnis, \& Fielding, 2012). Children in female-headed households are at greater risk of living in poverty (Bahamas Department of Statistics, 2004 \& 2014), so this may account for the fact that boys are encouraged to start work to contribute to household income.

One important sex difference, which may have influences beyond teen years, was that boys were more likely than girls to be engaged in employment. Consequently, from an early age, gender conditioning inculcates the view 
that the man will provide for the household and with that economic responsibility, certain rights are also earned (World Bank, 2012). The early introduction of boys to the market place, and its associated economic implications, may explain why boys expect themselves to be heads of households, rather than girls. However, it should be recognised that the need to earn money can put children at risk of being abused, for example through sexual exploitation (Dunn, 2002).

Over $80 \%$ of respondents had been on a date and so had had a relationship of some sort with the opposite sex; this figure is higher than the $61 \%$ reported in the United States of America (Teenage Research Unlimited, 2006). While this study cannot answer why this may be, it could be that if students do not receive support from homes or schools they may look to others for comfort and support. While not the focus of this study, we acknowledge the importance of adult support to children. In the Bahamian context, this represents an area which requires further research as previous studies have only obliquely visited this matter (Bahamas Ministry of Health, 2003 and Minnis, Symonette, Newry, Gibson \& Stevenson, 2011). It also suggests a lack of adult support for children.

Relatively few girls dated boys outside of their age group. Although this aspect of teenage behaviour has been reported as an area of concern in the news media (for example: Smith, 2012 April 2), it appears that girls dating boys slightly older than themselves was the norm. Barter et al. (2009) noted that when girls date boys two or more years older than themselves, they are at risk for becoming victims of emotional violence. Future research on those girls who do date older males and the circumstances surrounding such relationships is recommended.
A minority of teens approved of their partners being controlling, but contradicted this by their attitudes towards behaviours that could be considered as controlling. This may suggest that teenagers do not have a full appreciation of what behaviours are and are not controlling. The percentages of respondents in our study subjected to controlling behaviours were higher than those reported by teenagers in the United States (Teenage Research Unlimited, 2006). McEwen (2010) considered Bahamian homes to be subjected to "high levels of violence" ( $p$. 12) compared to the United Kingdom, and this violence may influence teen interactions.

In the United Kingdom, Barter et al. (2009) found that girls were more likely to exhibit controlling behaviours than boys, a finding similar to that of our study, but this sexrelated behaviour was less pronounced than in the United States (Teenage Research Unlimited, 2006) and contrary to a previous study in The Bahamas (Bahamas Ministry of Health, 2003) ${ }^{3}$. The data do not support the idea that boys are necessarily the leaders in teen relationships. If this is so, it presents a reversal of actions of adults where males are reported as controlling relationships and even fighting over women (Smith, 2012 June 5).

The controlling behaviours exhibited by teens can be expected to persist into adulthood. Students were concerned about (future) spouses having friends of the opposite sex. They indicate that women should do as they are told, or at least conform to the wishes of their male partners (e.g. dressing appropriately). The conservative culture of The Bahamas, often underpinned by the influential Bahamas Christian Council, a coalition of more recently established Christian sects (Bahamas Christian Council,

\footnotetext{
${ }^{3}$ Blank (2005) noted that boys were also pressured, and indicated that boys were more likely than girls to "definitely" feel pressured into having their first experience of sexual intercourse.
} 
n.d.), reinforces norms which include male leadership in homes. Therefore, these attitudes may moderate the attitudes regarding leadership in the household of women who are married or in long-term relationships. Attitudes concerning controlling behaviours include the expectation of both boys and girls that wives must always be willing to have sex with their husbands. Although there were sex differences in the responses, $16 \%$ of the girls thought that wives should provide their husbands with sex on demand. This attitude has implications for the debate in The Bahamas concerning a marital rape law (Benjamin \& LeGrand, 2012). Our data suggest that sexual expectations of future husbands and wives are formed at an early age, and this raises the question as to the origin of these expectations.

While married couples were expected to remain together, this contrasts with the reality within the respondents' homes as only $40 \%$ of respondents lived with both father and mother figures. Behaviours associated with men and women were often based on stereotypes. For example, women were expected to stay at home, but for most respondents the mother figure worked. Consequently there is a disconnection between reality (students having mothers who worked) and attitudes ("a woman's place is in the home"). These expectations may reflect the conservative nature of Bahaman society which is underpinned by fundamentalist Christian beliefs and orthodox statements by public figures (Nicolls, 2012).

The use of violence by female teenagers appears to be consistent with the negative image sometimes projected onto women through the Jezebel factor which portrays women as "sexually aggressive, immoral [and] domineering" (Marshall, 2006, p. 2). In The Bahamian context, the term "junglist" is applied to "very vulgar, very loud, very irreverent" women (Turnquest, 2012) who also use their sexuality for their own purposes. These images can provide an excuse for men to feel that they need to control "their" woman, as demonstrated by the perceived need by males to hit their partner to show who is in charge.

Attitudes towards violent behaviours in adulthood were linked only to a limited extent to violent behaviours in current relationship. The fact that "calling names" was linked with attitudes in adult relationships raises questions concerning what this action entails. Children are subject to being shouted at when at home (Carroll, et al, 2011) so it is something with which many children will be familiar. This suggests that name-calling within a relationship holds particular significance beyond that experienced at home. In the United States, name-calling has been shown to have important detrimental effects on teenagers (Teicher, 2010) and the importance of the physiological aspects of defective teen relationships has been demonstrated by Nansel et al. (2001).

The responses show that on a number of issues regarding relationships, boys and girls have different attitudes and behaviours. It can also been seen that large numbers of teens can be expected to be victims of controlling behaviours. The use of threats and physical force may be learnt behaviours due to the presence of violence in homes in The Bahamas. Children are sometimes subjected to violence from an early age and so they have ample opportunity to learn violence both at home and at school (Carroll et al., 2011).

The ultimate form of violence is murder. With arguments and domestic violence being key reasons for murder in The Bahamas (Hanna, 2010), these data suggest that there is a clear need for children to be taught how to respect one another from an early age. Again, the higher percentage of respondents in this study, compared to the percentage in a study 
in the United States (Teenage Research Unlimited, 2006), who threatened to use murder to maintain a relationship might suggest either that the relationship is deeply felt, or that students are anxious to maintain the relationship, no matter what. This may mean that they will have to unlearn behaviours learned from their peers. The treatment of pupils at school by teachers can either reinforce that violence is an effective form of control (McNeil, 2012) or provide teaching moments in conflict resolution. While teaching healthy relationships in schools can reach the majority of teenagers, over 1,000 teenagers do not attend school (UNESCO Institute for Statistics, 2013) and so are beyond the reach of instruction.

Overall, it is apparent that the breakdown in adult relationships, which is considered to play an important role in the violence observed in Bahamian society, may be the consequence of adolescents not adjusting their teen behaviours when they become adults. Therefore, modifying the attitudes of children with regard to interpersonal relationships may be important in reducing long-term violence in the country. Boys and girls had different attitudes on many aspects of relationships with current or future partners, but their endorsement of stereotypes of sex-related roles and their participation in certain behaviours could be a cause for concern. Underpinning these attitudes may be issues associated with what it means to be a woman or a man in The Bahamas (Strachan, 2013), and related gender norms. The fact that students found violence of any type acceptable in relationships may indicate their "normality" in Bahamian society. The differences in responses exhibited by boys and girls may need to be taken into account when teaching students about how to manage relationships. Sessions for the two sexes may need to be held separately, as well as jointly, depending on the material to be covered. Teaching teenagers about healthy relationships allows for differences in opinions (for example Lilley, 2003) but sexbased differences may pose additional difficulties in accommodating such sessions in the co-educational system that prevails in The Bahamas.

\section{CONCLUSIONS}

This study has informed the dialogue towards the appreciation of the nature of relationships between teenagers in The Bahamas. Both boys and girls subject each other, and are subjected to, controlling behaviours and violence in their relationships, with girls being no less aggressive than boys. The study indicates that teenagers expect males to be the controlling partners in adult relationships, and that women should conform to the stereotype of a housewife. Interventions at school can be useful in attempting to alter teenage relationships so that peer-on-peer abuse is reduced. However, culturally sensitive training can only be implemented once there is an understanding of the nature of these relationships, and of the expectations of teenagers for their adult relationships. Further research is required to determine the sources of teenage attitudes towards relationships and the impact of gender norms. Unless these are known, interventions at school may be both undermined and ineffectual.

\section{REFERENCES}

Bahamas Christian Council. (n.d.). The Bahamas Christian Council. Retrieved from http://www.thebahamaschristian council.com/\#

Bahamas Crisis Centre. (2011). [Prevalence and trends in violence against women and girls]. Unpublished raw data. 
Bahamas Crisis Centre. (2012). [Total number of new cases of children under 18 seen at TCC from 2007-2011.]. Unpublished raw data.

Bahamas Department of Social Services. (2012). [Child Abuse Statistics Commonwealth of The Bahamas 2011]. Unpublished raw data.

Bahamas Department of Statistics. (2004). Bahamas living conditions survey 2001. Nassau, Bahamas: Department of Statistics.

Bahamas Department of Statistics. (2012). Births 1970-2010. Retrieved from http://statistics.bahamas.gov.bs/download/ 084616400.pdf

Bahamas Department of Statistics. (2014). Household expenditure survey 2013. Retrieved from http://statistics.bahamas.gov.bs/news.php? cmd=view \&id=119

Bahamas Information Services. (2012). PM announces Urban Renewal Commission co-chairs. [Press release]. Retrieved from http://tinyurl.com/ptj2as9

Bahamas Ministry of Education. (2008). The Bahamas national education statistics digest 2006/2007. Nassau: Author.

Bahamas Ministry of Health. (2003). Caribbean health survey 2002. Nassau, Bahamas: The Ministry of Health.

Barter, C., McCarry, M., Berridge, D., \& Evans, K. (2009). Partner exploitation and violence in teenage intimate relationships. Retrieved from http://www.womenssupportproject.co.uk/u serfiles/file/partner_exploitation_and_viole nce_report_wdf70129.pdf

Benjamin, L., \& LeGrand, C. (2012). Sound and fury: Newspaper coverage of the marital rape debate in New Providence. International Journal of Bahamian
Studies, 18, 16-35. Retrieved from http://journals.sfu.ca/cob/index.php/files/ar ticle/view/164/219

Bethel, N., Minnis, J., \& Fielding, W. J. (2012). Knowing your ancestors: A survey of Bahamians' knowledge of their progenitor's names. International Journal of Bahamian Studies, 18, 1-5. Retrieved from http://journals.sfu.ca/cob /index.php/files/article/view/171/215

Blank, L. R. (2005). The situation of youth in The Bahamas. Nassau, Bahamas: InterAmerican Development Bank.

Carroll, M., Fielding, W. J., Brennen, S. \& Hutcheson, S. (2011, November 3). Rearing violence in Bahamian homes. Paper presented at the Violence Symposium at The College of The Bahamas, Nassau. Retrieved from http://www.cob.edu.bs/Research/Violence Symposium/ViolenceSymposium2011_Vio lenceinHomes.pdf

Coffino, B. (2009). The role of childhood parent figure loss in the etiology of adult depression: findings from a prospective longitudinal study. Attachment \& Human Development, 11(5), 445-470. doi:10.1080/14616730903135993

Concerning child abuse figures. (2014, January 14). [Editorial]. Nassau Guardian. Retrieved from http://www.thenassauguardian.com/opinio n/editorial/44283-concerning-child-abusefigures

Coy, J., \& Miller, M. (2014). Intimate partners who struggle with formal commitments: Attachment styles, major challenges, and clinical implications. American Journal of Family Therapy, 42(3), 232-242. doi:10.1080/01926187.2013.808138

Crooks, C. V., Chiodo, D., Zwarych, S., Hughes, R., \& Wolfe, D. A. (2013). 
Predicting implementation success of an evidence-based program to promote healthy relationships among students two to eight years after teacher training. Canadian Journal of Community Mental Health, 32, 125-138. doi:10.7870/cjcmh2013-010

Dunn, L. L. (2002). The Bahamas: The situation of children in the worst forms of child labour in a tourism economy: A rapid assessment. Port of Spain, Trinidad: ILO Subregional Office for the Caribbean.

Fukuroda, M. L. (2005). Murder at home: An examination of legal and community responses to intimate femicide in California. Los Angeles, CA: California Women's Law Center. Retrieved from http://www.cwlc.org/files/docs/MurderAtH ome_FULL_REPORT.pdf

Hanna, C. (2010). Reducing murders in The Bahamas: A strategic plan based on empirical research. Nassau, Bahamas: Royal Bahamas Police Force. Retrieved from http://www.bahamaslocal.com/files /Reducing_Murders_in_The_Bahamas.pdf

Henry, R. R., \& Zeytinoglu, S. (2012). African Americans and teen dating violence. American Journal of Family Therapy, 40(1) 20-32. doi:10.1080/01926187.2011.578033

Le Franc E., Samms-Vaughan, M., Hambleton I., Fox, K. \& Brown, D. (2008). Interpersonal violence in three Caribbean countries: Barbados, Jamaica, and Trinidad and Tobago. Pan American Journal of Public Health, 24(6), 409-21.

Lilley, T.G. (2003). Healthy relationships: Teen dating violence curriculum 9th-12th Grade. Retrieved from http://www.ilfvcc.org/local/11/Jen_Strategi es_-_Healthy_Relationships_and_ TDV_Five_day_program.pdf

Liu, H., Yu, S., Cottrell, L., Lunn, S.,
Deveaux, L., Brathwaite, N. V., Marshall, S., Li, X., \& Bonita, S. (2007). Personal values and involvement in problem behaviors among Bahamian early adolescents: a cross-sectional study. BMC Public Health, 135-152. doi:10.1186/14712458-7-135

Marshall, A. L. (2006, March). Jezebels, soca and dancehall divas: The impact of images of femininity upon social policies and gender relationships in the Caribbean. Paper presented at the Seventh Annual Conference, Barbados. Retrieved from http://www.cavehill.uwi.edu/salises/confer ences/past-conferences/2006/jezebels,soca-and-dancehall-divas---marshall.aspx

McEwen, F. (2010). Research review: Animal abuse, child abuse and domestic violence. Community Care Inform. Retrieved from http://www.ccinform.co.uk/Articles/2010/0 1/12/4231/Animal+abuse, +child+abuse+an d+domestic+violence.html

McNeil, D. (2012, March). An investigative study into the use of discipline and classroom management as it relates to the Ministry of Education's Rules and Procedures. Paper presented at The College of The Bahamas Student Research Symposium, Nassau.

Minnis, J., Symonette, E., Newry, Y., Gibson T., \& Stevenson, M. (2011). [Profile of inmates at H. M. Fox Hill Prison]. Unpublished raw data.

Moss-Knight, T. C. (2010). Experiences of pregnancy among adolescents in the Bahamas: A qualitative approach (Unpublished doctoral dissertation). Howard University, Washington, DC.

Nansel, T. R., Overpeck, M., Pilla, R. S., Ruan, W., Simons-Morton, B., \& Scheidt, P. (2001). Bullying behaviors among US youth: Prevalence and association with psychosocial adjustment. Journal of the 
American Medical Association, 285(16), 2094-2100. Retrieved from http://jama.jamanetwork.com/article.aspx? articleid $=193774$

Nicolls, N. (2012, June 11). Christian cloak protecting misogynists. The Tribune.

Retrieved from http://www.tribune242.com/news/2012/jun /11/christian-cloak-protecting-misogynists/

Otterbein, C. S., \& Otterbein, K. F. (1973). Believers and beaters: A case study of supernatural beliefs and child rearing in the Bahama Islands. American Anthropologist, 75(5), 1670-1681.

doi:10.1525/aa.1973.75.5.02a00290

Reynolds, M. (2009, July 8). Teachers curse, call us names and throw objects. The Tribune. Retrieved from http://www.tribune242.com/Print/0708200 9_findings_news_pg3/

Risley-Curtiss, C., \& Fielding, W. J. (2012). [Violence in the homes of college students in The Bahamas and the USA]. Unpublished raw data.

Royal Bahamas Police Force. (n.d). [Sexual assault cases 2000-2013]. Unpublished raw data.

Smith, D. (2012, April 2). Girls paying for school with sex. The Tribune. Retrieved from http://www.tribune242.com/news/2012/apr /02/girls-paying-for-school-with-sex/

Smith, D. (2012, June 5). Arguments over women blamed for rising murder rate. The Tribune. Retrieved from http://www.tribune242.com/news/2012/jun /05/arguments-over-women-blamed-forclimbing-murder/?news

Strachan, I. (2013). I's man. Manhood in the Bahamas. [DVD]. Nassau, Bahamas: Author.

Teenage Research Unlimited. (2006). Liz
Claiborne Inc. Topline findings. Teen relationship abuse survey. Northbrook, IL: Author. Retrieved from https://www.breakthecycle.org/sites/default /files/pdf/survey-lina-2006.pdf

Teicher, M. H., Samson, J. A., Sheu, Y., Polcari, A., \& McGreenery, C. E. (2010) Hurtful words: Association of exposure to peer verbal abuse with elevated psychiatric symptom scores and corpus callosum abnormalities. American Journal of Psychiatry, 167, 1464-1471. doi:10.1176/appi.ajp.2010.10010030

Tharp, A., Burton, T., Freire, K., Hall, D. M., Harrier, S., Latzman, N. E., \& ... Vagi, K. J. (2011). Dating matters: Strategies to promote healthy teen relationships. Journal of Women's Health, 20(12), 1761-1765. doi:10.1089/jwh.2011.3177

Turnquest, A. (2012, May 30)). Apocalypto play parodies Bahamian society. The Tribune. Retrieved from http://www.tribune242.com/news/2012/ma y/30/apocalypto-play-parodies-bahamiansociety/

U.S. Department of State. Overseas Security Advisory Council. (2012.). Bahamas 2012 crime and safety report. Retrieved from https://www.osac.gov/Pages/ContentRepor tDetails.aspx ?cid $=12460$

UNESCO Institute for Statistics. (2013). eAtlas of out-of-school children. Retrieved from http://tellmaps.com/uis/oosc/

UNICEF. (2006). Violence against children in the Caribbean region, Regional assessment: UN Secretary General's study on violence against children. Retrieved from http://www.unicef.org/lac /Caribe_web\%281\%29.pdf

UNICEF. (2011). State of the world's children 2011: Adolescence an age of opportunity. New York, NY: UNICEF. 
United Nations Office on Drugs and Crime and the Latin America and the Caribbean Region of the World Bank. (2007). Crime, violence and development: trends, costs and policy options in the Caribbean.

Retrieved from http://www.worldbank.org/INTHAITI/Res ources/Crimeandviolenceinthecaribbeanful lreport.pdf

Weller, P., \& Clifford, M. (2008). Caribbean men talking about manhood: Caribbean male action network. Kingston, Jamaica: Lithographic Printers.

World Bank. (2012). World development report 2012: Gender equality and development. Retrieved from

http://www.worldbank.org/INTWDR2012/

Resources/7778105-

1299699968583/7786210-

1315936222006/Complete-Report.pdf

Yu, S., Deveaux, L., Lunn, S., Liu, H., Brathwaite, N., Li, X., Cottrell, L., Marshall, S., \& Stanton, B. (2007). At greatest risk: Pre- and early adolescent Bahamian youth experiencing anal intercourse. International Journal of STD \& AIDS, 18, 396-401. doi:10.1258/095646207781024784 